\title{
ATAP OTOMATIS SENSOR SUHU, AIR DAN TENAGA SURYA (ALAS TSUSU)
}

\author{
Koko Hendriawan \\ Program Studi Teknik Informatika, Universitas Negeri Semarang \\ hendriawan.koko@gmail.com
}

\begin{abstract}
ABSTRAK
Atap otomatis sensor suhu,sensor air dan surya(ALAS TSUSU) sebagai inovasi desain atap yang dapat membuka dan menutup secara otomatis.Atap adalah salah satu komponen yang sangat penting dalam sebuah bangunan. Dengan adanya dua musim yang di miliki Negara Indonesia Antara musim hujan dan kemarau atap tidak hanya sebagai fungsi utama dalam melidungi kita dari matahari dan hujan akan tetapi juga memiliki nilai estetika yang sangat tinggi misalnya intensitas cahaya yang diterima bumi kurang terang dengan rain probability (kemungkinan turun hujan) tinggi. Sedangkan pada musim kemarau, sinar matahari lebih terang dengan kemungkinan turun hujan sangat rendah, bahkan hampir tidak pernah turun hujan. Sehingga rancangan dari sebuah atap di haruskan mendapatkan perhatian yang serius. Metode pelaksanaan dalam pembuatan Atap otomatis sensor suhu,sensor air dan surya(ALAS TSUSU) adalah membuat sebuah prototype atap yang inovatif dan mensetting sensor air dan suhu sehingga atap tersebut akan bergerak secara otomatis bila terjadi perbedaan suhu dan terkena air.Prototype ini dikatakan berhasil jika mampu atap yang dibuat dapat bergerak dengan bantuan sensor dan tenaga listrik yang bersumber dari panel surya.
\end{abstract}

Kata Kunci: ALAS TSUSU, sensor Air, sensor Suhu.

\section{PENDAHULUAN}

Dewasa ini, kemajuan perkembangan teknologi sangatlah pesat. Hal tersebut telah mempermudah urusan manusia dalam aktifitasnya. Namun, Atap yang mayoritas di gunakan Indonesia mayoritas belum memanfaatkan energi alam. Energi baru dan terbarukan mulai mendapatkan perhatian sejak terjadinya krisis energi dunia yaitu pada tahun 70an dan salah satu energi itu adalah energi surya. Energi listrik yang berasal dari energi surya pertama kali digunakan untuk penerangan rumah tangga dengan sistem desentralisasi yang dikenal dengan Solar Home Sistem (SHS), kemudian untuk TV umum, komunikasi dan pompa air (Kadir, 1982).

Atap adalah salah satu komponen yang sangat penting dalam sebuah bangunan. Dengan adanya dua musim yang di miliki Negara Indonesia Antara musim hujan dan kemarau atap tidak hanya sebagai fungsi utama dalam melidungi kita dari matahari dan hujan akan tetapi juga memiliki nilai estetika yang sangat tinggi misalnya intensitas cahaya yang diterima bumi kurang terang dengan rain probability (kemungkinan turun hujan) tinggi. Sedangkan pada musim kemarau, sinar matahari lebih terang dengan kemungkinan turun hujan sangat rendah, bahkan hampir tidak pernah turun hujan. Sehingga rancangan dari sebuah atap di haruskan mendapatkan perhatian yang serius. Beberapa dari kita mungkin pernah melihat atap buka tutup National Stadion dari Singapura dengan total biaya $\$ 1,87$ miliar yang memiliki system atap buka tutup (Wikipedia) dan dari bekasi bernama Atap Sun Shading dengan total biaya 16 juta yang memiliki fungsi atap buka tutup juga. Akan tetapi dari 2 sumber tersebut tidak ekonomisdan kurang memanfaatkan energy di sekitar alam, dari harga yang terlalu mahal semua orang tidak dapat merasakan menggunakan atap otomatis buka tutup, dan hanya menjadi hayalan untuk dapat menggukan atap otomatis buka tutup di rumah, dan stadion yang ada di Indonesia. ALAS TSUSU adalah sebuah atap yang memiliki 
desain modern dan di khususkan untuk di sekitar rumah maupun stadion yang ada di Indonesia. Masalah yang terjadi di rumah adalah saat kita menjemur pakaian terkadang kita lupa akan pakaian yang kita jemur sehingga ketika hujan turun baju yang kita jemur basah kembali, dan permasalahan juga terjadi di beberapa stadion sepak bola yang ada di indonesia ketika kita menonton pertandingan bola kita tidak dapat memprediksi hujan yang akan turun, sehingga ketika hujan turun kita juga ikut terkena hujan dan tidak dapat menikmati sepenuhnya dengan pertandingan yang terjadi.

Oleh karena itu kita ingin menciptakan sebuah alat yang kita beri nama Alas Tsusu (Atap elastrik tenaga sensor suhu dan surya). Sehingga Target yang di harapkan dari Alas Tsusu yaitu menjadi produk yang mampu diaplikasikan dan bermanfaat dalam upaya pemanfaatan energy alam, serta membantu pemerintah dalam upaya memodernisasi desain atap di Indonesia.

\section{METODE}

Pada pelaksanaan dilapangan yang pertama adalah membuat atap yang ada pada proposal. Pada proses pembuatan atap menggunakan motor servo sebagai penggeraknya. Langkah berikutnya adalah membuat skema arus listrik yang sesuai dan efektif untuk menggerakkan atap yang sudah dibuat. Langkah berikutnya, memprogram microcontroller Arduino Uno R3 dengan bahasa $C$ yang berfungsi sebagai otak untuk sensor air dan sensor suhu supaya dapat bekerja. Dasar dari pengkonfigurasian microcontroller untuk sensor dan atap adalah dengan memutus arus listrik dan membolak-balikkan arus listrik. Pada sensor suhu, akan diatur suhu normal adalah $29 \mathrm{oC}-$ $310 \mathrm{C}$ dan suhu paling rendah akan diatur sebesar $25 \mathrm{oC}-28 \mathrm{oC}$ dan suhu tertinggi akan diatur sebesar 32oC-34oC. Pada saat suhu normal maka atap akan membuka dengan sendirinya dengan cara mengalirkan listrik pada motor secara normal supaya motor akan bergerak ke kanan. Sebaliknya pada saat suhu terendah atau tertinggi, atap akan tertutup dengan sendirinya dengan cara mengalirkan arus listrik secara terbalik pada motor supaya motor akan bergerak ke kiri. Kemudian untuk mensetting sensor air, ditentukan kadar air sebesar 90\% untuk menggerakkan atap supaya menutup. Langkah berikutnya adalah instalasi panel surya. Listrik yang akan dihasilkan panel surya tidak langsung bergerak ke microcontroller namun akan ditampung dalam baterai yang kemudian akan disalurkan ke microcontroller.

\section{HASIL DAN PEMBAHASAN}

\section{Membuat rancangan arus listrik}

Setelah pembagian tugas di berikan kemudian langkah awal kami adalah membuat rancangan arus listrik untuk cara kerja dari prototype kami.

\section{Pembuatan atap}

Setelah rancangan arus listrik dibuat, pembuatan pertama yang kami fokuskan adalah pembuatan atapnya terlebih dahulu. Atap yang dibuat menggunakan motor servo dan untuk on dan off menggunakan saklar. Pada tahap ini kami memfokuskan supaya atap dapat bergerak terlebih dahulu.

\section{Pembelian bahan-bahan}

Setelah atap sudah berfungsi sebagai mana mestinya, selanjutnya kami membeli bahanbahan pendukung seperti sensor air, sensor suhu,microcontroller.

4. Evaluasi hasil atap dengan pembimbing

Setelah atap yang sebelumnya masih menggunakan saklar telah jadi. Kemudian kami melakukan evaluasi kepada pembimbing kami. Dan hasilnya harus membuat prototype menjadi kokoh dan lebih baik lagi 


\section{SIMPULAN}

Atap otomatis sensor suhu,sensor air dan surya(ALAS TSUSU) sebagai inovasi desain atap yang dapat membuka dan menutup secara otomatis. Atap adalah salah satu komponen yang sangat penting dalam sebuah bangunan. Dengan adanya dua musim yang di miliki Negara Indonesia Antara musim hujan dan kemarau atap tidak hanya sebagai fungsi utama dalam melidungi kita dari matahari dan hujan akan tetapi juga memiliki nilai estetika yang sangat tinggi misalnya intensitas cahaya yang diterima bumi kurang terang dengan rain probability (kemungkinan turun hujan) tinggi. Sedangkan pada musim kemarau, sinar matahari lebih terang dengan kemungkinan turun hujan sangat rendah, bahkan hampir tidak pernah turun hujan. Sehingga rancangan dari sebuah atap di haruskan mendapatkan perhatian yang serius. Metode pelaksanaan dalam pembuatan Atap otomatis sensor suhu,sensor air dan surya(ALAS TSUSU) adalah membuat sebuah prototype atap yang inovatif dan mensetting sensor air dan suhu sehingga atap tersebut akan bergerak secara otomatis bila terjadi perbedaan suhu dan terkena air. Prototype ini dikatakan berhasil jika mampu atap yang dibuat dapat bergerak dengan bantuan sensor dan tenaga listrik yang bersumber dari panel surya.

\section{DAFTAR RUJUKAN}

Harjunowibowo, Dewanto.2010. Model Panel Surya Cerdas dengan SensorPelacakCahaya Matahari Otomatis BerbasisMikrokontroler. JurnalBerkala Fisika, 13 (2): B7B14

Hibbeler, R., C., 2002, Struktur Analysis (Fifth Edition), Printice Hall, Arsitektur Unversitas Katolik Soegijapranata. https://atapfiberglobal.wordpress.com/(di akses pada tanggal 5 september 2015)

http://elektroforindependent.blogspot.co.id/2 011_11_01_archive.html(diakses pada tanggal 5 september 2015)

http://misimini.blogspot.co.id/2013/09/simul asi-sensor-suhu-padaproteus.html(diakses pada tanggal 5 september 2015)

https://pixabay.com/en/solar-cells-energycurrent-100445/ di akses pada tanggal 5 september 2015)

http://teknikelektronika.com/pengertiansensor-suhu-jenis-jenis-sensorsuhu/(diakses pada tanggal 2 september 2015)

http://www.lelong.com.my/saga-powerwindow-motor 83859182-2012-05Sale-P.htm (di akses pada tanggal 5 september 2015)

http://www.lintang-aluminium.com/kanopiatap-buka-tutup-lovera-di-bekasi/ (diakses pada tanggal 2 september 2015)

http://www.pawbio.com/techsensor.html(diakses pada tanggal 5 september 2015)

http://www.searchesinteractive.com/?pid=9P O96133D\&dn=free-blogcontent.com\&rpid $=9 \mathrm{POO} 358 \mathrm{~K} 6(\mathrm{di}$ akses pada tanggal 5 september 2015)

http://www.searchesinteractive.com/?pid=9P O96133D\&dn=free-blogcontent.com\&rpid $=9 \mathrm{POO} 358 \mathrm{~K} 6(\mathrm{di}$ 
akses pada tanggal 5 september 2015)

Ibrahim, KF. 1996. Teknik Digital. Yogyakarta: ANDI Offset

Muslim, Much Aziz; Prasetiyo Budi. 2015. ARSITEKTUR KOMPUTER. Edisi Pertama - Semarang; FMIPA UNNES.

Pasaribu, Alex. 2009. Aplikasi Mikrokontroler AT89S51 Untuk sistem Pengatur Buka/Tutup Atap dan Pemanas Ruangan. Universitas Sumatra Utara (skripsi tidak diterbitkan)

Ramayana, Harry. 2004. Kajian Bahan Penutup Atap Bangunan di Daerah Pegunungan. Semarang: Seminar
Arsitektur Fakultas Teknik Jurusan New Jersey.

Sutrisno. 1987. Elektronika: Teori dan Penerapannya. Bandung: ITB.

Timoshenko, S., $\mathrm{P}$ dan Gere, J., 2000, Mekanika Bahan Jilid 1 (Edisi IV), Erlangga, Jakarta.

Timoshenko, S., P dan Gere, J., 2000, Mekanika Bahan Jilid 2 (Edisi IV), Erlangga, Jakarta.

Wallace, J.A., 2001, Testing of Bolted ColdFormed Steel Connections in Bearing(with and without Washers), final report canadian cold formed steel research group, Department of Civ Engineering University of Waterloo, Ontario, Canada 